\title{
Characterization of thermophilic fungi producing extracellular lignocellulolytic enzymes for lignocellulosic hydrolysis under solid-state fermentation
}

\author{
Paramjeet Saroj, Manasa P and Korrapati Narasimhulu*
}

\begin{abstract}
Background: Thermotolerant lignocellulolytic enzymes have become a subject of interest in industrial processes due to their ability to degrade lignocellulosic polysaccharides. Development of cost-effective, large-scale screening for production of desirable enzymes by thermophilic fungi is a challenge. The present investigation focused on isolating, screening, and identifying industrially relevant thermophilic producers of lignocellulolytic enzymes from various locations in the Warangal district, Telangana, India.

Results: Fifteen thermophilic fungi were isolated from soil on their ability to grow at $50^{\circ} \mathrm{C}$ and were screened for their activity of cellulase, hemicellulase, and lignin degradation based on holo zone around colonies. The appearance of the black color zone of diffusion in esculin agar is a positive indication for the $\beta$-glucosidases activity test. Out of fifteen isolates, Aspergillus fumigatus JCM 10253 have shown as a potential producer of extracellular enzymes for lignocelluloses degradation showing higher activity for cellulase (El 1.50) as well as $\beta$-glucosidase ( $4 \mathrm{mg} / \mathrm{mL}$ ), simultaneously for xylanase (EI 1.18) by plate assay methods. A. fumigatus JCM 10253 was selected for extracellular hydrolytic enzymes production under solid-state fermentation. Maximum CMCase (26.2 IU/mL), FPase (18.2 IU/mL), $\beta$-glucosidase $(0.87 \mathrm{IU} / \mathrm{mL})$, and xylanase $(2.6 \mathrm{IU} / \mathrm{mL})$ activities were obtained after incubation time of $144 \mathrm{~h}$ at $50{ }^{\circ} \mathrm{C}$. The thermostability of crude cellulase showed the optimum activity at $60^{\circ} \mathrm{C}$ and for FPase, $\beta$-glucosidase, and xylanase at $50{ }^{\circ} \mathrm{C}$ which recommended that the enzymes have a potentially significant role in the biofuel industries.
\end{abstract}

Conclusion: The high titer production of active enzymes that cleave different $\beta-1,4$-glycosidic bonds still remains a challenge and is the major bottleneck for the lignocellulosic conversion. In particular, the finding of thermostable enzymes which would allow the development of more robust processes is a major goal in this field.

Keywords: Lignocellulolytic enzymes, Cellulase, Hemicellulase, $\beta$-Glucosidase, Aspergillus fumigatus, Hydrolytic enzymes, Solid-state fermentation

\section{Background}

Increasing global energy needs and greenhouse gas emissions have had a significant impact on ecosystem stability and the environment. Therefore, there is a need to find alternative sources of energy to replace existing fossil fuel resources. The conversion of lignocellulosic biomass

*Correspondence: simha_bt@nitw.ac.in

Department of Biotechnology, National Institute of Technology, Warangal, Telangana 506004, India into material for the production of biofuels is a potential alternative energy source with several advantages (Arora et al. 2015). Lignocellulose, composed mainly of cellulose, hemicelluloses, and lignin, is the main component of the plant cell wall (Lynd et al. 2002). Lignocellulose has a complex molecular structure, which blocks enzymes and thus, prevents the degradation of the biomass into fermentable sugars. However, producing sustainable biofuels from lignocellulosic biomass in a cost-effective way is a significant challenge in the commercialization 
of the production process (Behera et al. 2014). Additionally, chemical hydrolysis of lignocelluloses results in the formation of toxic components that are hazardous to the environment. Microbes are known to produce enzyme complexes that degrade plant biomass, offering an efficient and cost-effective alternative (Behera et al. 2013).

Cellulose is a linear polymer chain of repeating units of cellobiose joined by $\beta-1,4$ linkages. Cellulose chains interact with each other via hydrogen bonds, resulting in the formation of a rigid, insoluble crystalline structure (Yamada et al. 2013). Three specific enzymes act synergistically to degrade cellulose into glucose, including endoglucanase (EC 3.2.1.4), exoglucanase (EC 3.2.1.91), and $\beta$-glucosidase (EC 3.2.1.21) (Garvey et al. 2013; Juturu and Wu 2014). Endoglucanase cleaves cellulose fibers into small fragments, releasing free reducing and non-reducing ends. Exoglucanase acts on non-reducing ends to release small cellobiose oligosaccharides. Finally, $\beta$-glucosidase converts cellobiose into monomeric sugars (Singhania et al. 2013). $\beta$-Glucosidases is a rate-limiting factor in the process of converting cellulose to glucose for bioethanol production. In the absence of $\beta$-glucosidase activity, cellobiose oligosaccharides accumulate, causing end-product inhibition and limiting hydrolysis yields (Suwannarangsee et al. 2012). Hence, commercially available cellulolytic preparations are usually added along with $\beta$-glucosidase to increase overall activity. Xylanases (EC 3.2.1.8) are a class of hydrolytic enzymes that can hydrolyze the polysaccharide 1,4-xylan found in hemicelluloses (Ramanjaneyulu et al. 2015).

Since commercial processes require high temperatures, thermostable enzymes are necessary for industrial use. Therefore, there is an increasing demand for thermophilic and thermostable producers of cellulolytic and hemicellulolytic enzymes, particularly those that are resistant to product inhibition and highly stable (Arora et al. 2014; Mallerman et al. 2015). Recently, thermophilic fungal enzymes have become the subject of increased interest due to their ability to produce highly efficient, thermostable extracellular enzymes for plant biomass degradation at elevated temperatures. Degradation of lignocellulose by fungi is achieved by producing extracellular hydrolytic and oxidative ligninolytic enzymes. The hydrolytic enzymes cellulase and hemicellulase degrade polysaccharides into simple sugars, whereas ligninolytic ligninase enzymes degrade lignin and open phenyl rings (Sánchez 2009).

Economically feasible enzyme production can be applied to the development of technologies that utilize cellulosic material as a renewable resource. The main objective of the present study was to screen and characterize thermophilic fungal isolates based on their ability to produce extracellular lignocellulolytic enzymes and to degrade lignin and open phenyl rings, using plate assays. Based on the zone of inhibition, potential strains were selected for assessment of enzyme production using solid-state fermentation. Thermostability of respective enzymes was investigated.

\section{Methods}

\section{Isolation and identification}

Warangal district is a part of the northern Telangana of newly formed Telangana State, India. It is situated approximately between the latitude of $17^{\circ} 19^{\prime}$ and $18^{\circ} 13^{\prime}$ North latitude of and $78^{\circ} 49^{\prime}$ and $80^{\circ} 43^{\prime}$ East latitudes. The soils of the Warangal city consist of sandy loams with patches of shallow black cotton soils and at places even medium and deep cotton soils. The weather of Warangal district is generally dry. Summers are hot sometimes, temperature reaches $50{ }^{\circ} \mathrm{C}$. The temperature drops to $13{ }^{\circ} \mathrm{C}$ in winter seasons during the months of December and January (Narasimha Ramulu and Benarjee 2016).

Soil samples were collected in sterile polythene bags from different sites in the Warangal district and were stored at $4{ }^{\circ} \mathrm{C}$. Emerson Yeast Soluble Starch (YSS) agar media (4 g/L yeast extract, $15 \mathrm{~g} / \mathrm{L}$ soluble starch, $1.0 \mathrm{~g} / \mathrm{L} \mathrm{K}_{2} \mathrm{HPO}_{4}, 0.5 \mathrm{~g} / \mathrm{L} \mathrm{MgSO}_{4} \cdot 7 \mathrm{H}_{2} \mathrm{O}$, and $20 \mathrm{~g} / \mathrm{L}$ agar, $\mathrm{pH} 7.0 \pm 0.2)$ and malt extract agar (MEA) $(20 \mathrm{~g} / \mathrm{L}$ malt extract, $20 \mathrm{~g} / \mathrm{L}$ dextrose, $6 \mathrm{~g} / \mathrm{L}$ peptone, and $15 \mathrm{~g} / \mathrm{L}$ agar) were used for fungal isolation experiments. Pure cultures were obtained by serial dilution. Inoculated agar plates were incubated at $30{ }^{\circ} \mathrm{C}$ and monitored at regular intervals for 10 days to assess fungal growth. Isolated fungi were sub-cultured on Emerson YSS agar slants and stored at $4{ }^{\circ} \mathrm{C}$. A loopful spore of fungal strain was inoculated into Sabouraud Dextrose Broth (dextrose $20 \mathrm{~g} / \mathrm{L}$, peptone $10 \mathrm{~g} / \mathrm{L}, \mathrm{pH} 5.6 \pm 0.2$ ) for 7 days in the incubator shaker at $30^{\circ} \mathrm{C}$.

\section{Screening and identification of thermophilic fungi}

To assess thermostability, isolated fungi were grown at temperatures between 30 and $50{ }^{\circ} \mathrm{C}$. Fungi were inoculated at the center of the plate and radial growth patterns were monitored for 7 days. Based on the growth patterns at different temperatures, fifteen thermophilic fungi were selected for plate assays. Isolated thermophilic fungi were identified based on 18S rRNA sequence analyses performed by Gujarat State Biotechnology Mission, Department of Science and Technology, Gandhinagar, Gujarat, India.

\section{Plate assay for cellulase and xylanase activity}

The thermophilic fungal isolates were screened for their ability to degrade cellulose and hemicelluloses using Czapek-Dox media (30 g/L sucrose, $2 \mathrm{~g} / \mathrm{L} \mathrm{NaNO}_{3}, 1 \mathrm{~g} / \mathrm{L}$ $\mathrm{K}_{2} \mathrm{HPO}_{4}, 0.05 \mathrm{~g} / \mathrm{L} \mathrm{MgSO}$, $0.5 \mathrm{~g} / \mathrm{L} \mathrm{KCl}, 0.01 \mathrm{~g} / \mathrm{L} \mathrm{FeSO}_{4}$, 
and $20 \mathrm{~g} / \mathrm{L}$ agar) (Kluepfel 1988) containing 1\% carboxymethyl cellulose (CMC) as the substrate for cellulase and $1 \%$ beechwood as the substrate for xylanase (Hölker et al. 2004). The $\mathrm{pH}$ was adjusted to 5.0 and the media were autoclaved. Sterile agar medium was poured into sterile Petri dishes and allowed to solidify. About 0.4-cm-diameter wells were made on solidified agar plates. A total of $16 \mu \mathrm{L}$ of fungal broth was pipetted into each well and the plates were sealed with Parafilm and incubated at $50{ }^{\circ} \mathrm{C}$ for 7 days. Fifteen thermophilic fungi were then screened for cellulase and xylanase activity using Congo red ( $1 \%$ aqueous) solution (Ahirwar et al. 2017). After incubation at $50{ }^{\circ} \mathrm{C}$ for 7 days, culture plates were flooded with Congo red and left for $30 \mathrm{~min}$, then destained by washing twice with $1 \mathrm{M} \mathrm{NaCl}$ for 20 min on a gel rocker. Transparent hydrolytic zones where cellulose and xylan were degraded into simple sugars were observed. The enzymatic index (EI) was calculated by measuring the clearance zone and using the following expression (Teather and Wood 1982; Bradner et al. 1999; Ruegger and TaukTornisielo 2004; Pečiulytè 2007; Florencio et al. 2012):

$$
\text { Enzymatic index }=\frac{\text { Diameter of hydrolysis zone (in cm) }}{\text { Diameter of the colony (in } \mathrm{cm})} .
$$

The growth of fungal isolates on MEA was taken as control. The inhibition index was calculated using the ratio of the diameter of the colony on CMC or xylan agar to the diameter of the colony on control agar (Khokhar et al. 2012). Each experiment was performed in triplicate.

\section{Esculin gel diffusion assay}

Esculin gel diffusion assay was used to assess $\beta$-glucosidase activity (Saqib and Whitney 2006). About $3 \%$ of agar in $0.2 \mathrm{M}$ sodium acetate buffer of $\mathrm{pH}$ 5 was autoclaved and kept at $50{ }^{\circ} \mathrm{C}$ to avoid agar solidification. Esculin (0.2\%) was mixed with $6 \mathrm{~mL}$ of $1 \% \mathrm{FeCl}_{3}$ and heated to $50{ }^{\circ} \mathrm{C}$ in a water bath. Both solutions were mixed thoroughly and poured into $15-\mathrm{cm}$ Petri dishes. The esculin agar was allowed to solidify and wells $0.4 \mathrm{~cm}$ in diameter were made. A total of $16 \mu \mathrm{L}$ of fungal broth was pipetted into each well and the plates were sealed with Parafilm and incubated at $37^{\circ} \mathrm{C}$ for $5 \mathrm{~h}$. After incubation, the plates were transferred to an ice bath to slow down enzyme activity. Plates were assessed for the appearance of a dark zone indicating esculin hydrolysis. Each experiment was performed in triplicate.

\section{Plate assay for lignin degradation and laccase activity}

Thermophilic fungal isolates were screened for their ability to degrade lignin polymers using lignin (alkaline) as a substrate following the method described by Tekere et al. (2001). The reaction mixture contained $0.25 \%(\mathrm{w} / \mathrm{v})$ lignin (alkaline), $5 \mathrm{~g} / \mathrm{L}$ glucose, $5 \mathrm{~g} / \mathrm{L}$ ammonium tartrate, $0.5 \mathrm{~g} / \mathrm{L} \mathrm{MgSO}_{4} \cdot \mathrm{H}_{2} \mathrm{O}, 1 \mathrm{~g} / \mathrm{L}$ malt extract, $0.01 \mathrm{~g} / \mathrm{L}$ $\mathrm{CaCl}_{2} \cdot 2 \mathrm{H}_{2} \mathrm{O}, 0.01 \mathrm{~g} / \mathrm{L} \mathrm{FeCl} 3,0.1 \mathrm{~g} / \mathrm{L} \mathrm{NaCl}, 1 \mathrm{mg} / \mathrm{L}$ thiamine, and $20 \mathrm{~g} / \mathrm{L}$ agar and was autoclaved. Sterile lignin agar medium was poured into sterile Petri dishes and allowed to solidify. Wells $0.4 \mathrm{~cm}$ in diameter were made on the solidified agar plates. A total of $16 \mu \mathrm{L}$ of test culture was pipetted into each well and the plates were sealed with Parafilm and incubated at $50{ }^{\circ} \mathrm{C}$ for 7 days. After 7 days, mycelia were scratched from the plate surface and flooded with a $1 \% \mathrm{FeCl}_{3}$ and $\mathrm{K}_{3}\left[\mathrm{Fe}(\mathrm{CN})_{6}\right]$ solution. The distance across each clearance zone, indicating degraded lignin, was measured.

Thermophilic fungi were examined for their ability to produce laccase, which is involved in lignin degradation, using guaiacol agar medium $(0.02 \% \mathrm{w} / \mathrm{v}$ guaiacol, $1 \% \mathrm{w} / \mathrm{v}$ yeast extract, and $2 \% \mathrm{w} / \mathrm{v}$ agar). A total of $16 \mu \mathrm{L}$ of test culture was pipetted into each well and plates were incubated at $50{ }^{\circ} \mathrm{C}$ in the dark for 7 days to ensure adequate growth of cultures in the medium (Singh et al. 2013).

\section{Enzyme production in shaking flasks}

Aspergillus fumigatus JCM 10253 was selected from the fifteen isolates as a potential producer of hydrolytic enzymes and used in further experiments. Mandels and Weber (1969) medium supplemented with 1\% $\mathrm{CMC}$ or beechwood as a carbon source and $2.5 \%$ wheat bran as a substrate was used for shaking flask fermentation experiments. The medium was prepared as follows: $2 \mathrm{~g} / \mathrm{L} \mathrm{KH}_{2} \mathrm{PO}_{4}, 0.3 \mathrm{~g} / \mathrm{L} \mathrm{CaCl} \cdot 2 \mathrm{H}_{2} \mathrm{O}, 0.3 \mathrm{~g} / \mathrm{L}$ urea, $0.3 \mathrm{~g} / \mathrm{L} \mathrm{MgSO}_{4} \cdot 7 \mathrm{H}_{2} \mathrm{O}, 1.4 \mathrm{~g} / \mathrm{L}\left(\mathrm{NH}_{4}\right)_{2} \mathrm{SO}_{4}, 0.25 \mathrm{~g} / \mathrm{L}$ peptone, $0.1 \mathrm{~g} / \mathrm{L}$ yeast extract, $1 \mathrm{~mL}$ Tween-80, $0.005 \mathrm{~g} / \mathrm{L}$ $\mathrm{FeSO}_{4} \cdot 7 \mathrm{H}_{2} \mathrm{O}, \quad 0.0016 \mathrm{~g} / \mathrm{L} \quad \mathrm{MnSO}_{4} \cdot \mathrm{H}_{2} \mathrm{O}, \quad 0.0014 \mathrm{~g} / \mathrm{L}$ $\mathrm{ZnSO}_{4} \cdot 7 \mathrm{H}_{2} \mathrm{O}$, and $0.002 \mathrm{~g} / \mathrm{L} \mathrm{CoCl}_{2} \cdot 6 \mathrm{H}_{2} \mathrm{O}$, pH 5 . The prepared medium was sterilized at $121{ }^{\circ} \mathrm{C}, 15$ psi. A loopful of spores of the isolated fungal strain A. fumigatus JCM 10253 was inoculated into the medium. Conical flasks were incubated at $50{ }^{\circ} \mathrm{C}$ with shaking at $160 \mathrm{rpm}$ for 12 days.

\section{Enzyme assays}

The extracellular total protein content of the culture filtrate was estimated using a Bradford assay (Bradford 1976). Carboxymethyl cellulase (CMCase) and filter paper activity (FPase) assay were performed according to the methods described by Ghose (1987). The assay for $\mathrm{CMCase}$ was carried out at $50{ }^{\circ} \mathrm{C}$ with a reaction mixture containing $0.5 \mathrm{~mL}$ crude enzyme and $0.5 \mathrm{~mL}$ of $2 \%$ substrate $(\mathrm{CMC})$ dissolved in $50 \mathrm{mM}$ sodium citrate buffer (pH 4.8) and incubated for $30 \mathrm{~min}$. FPase activity was performed by incubating $0.5 \mathrm{~mL}$ of the crude enzyme 
with $1 \mathrm{~mL} 50 \mathrm{mM}$ sodium citrate buffer $(\mathrm{pH} 4.8)$ containing Whatman No. 1 filter paper strip $(1 \mathrm{~cm} \times 6 \mathrm{~cm})$ for $60 \mathrm{~min}$ at $50{ }^{\circ} \mathrm{C}$. Xylanase assay was carried out according to the method described by Bailey et al. (1992). The activity was determined by incubating $0.2 \mathrm{~mL}$ of the crude enzyme with $1.8 \mathrm{~mL}$ of $1 \%$ beechwood dissolved in $50 \mathrm{mM}$ sodium citrate buffer ( $\mathrm{pH} 5.0)$ at $50{ }^{\circ} \mathrm{C}$ for $5 \mathrm{~min}$. All the above reaction was stopped by adding $3 \mathrm{~mL}$ of 3,5-dinitrosalicylic acid (DNS) reagent and heating for $10 \mathrm{~min}$ in a boiling water bath. The amount of reducing sugar released was measured using a UV-visible spectrophotometer (Model: Jasco-V-630) at $540 \mathrm{~nm}$. $\beta$-Glucosidase activity was analyzed using $p$-nitrophenyl$\beta$-D-glucopyranoside as a substrate according to the method described by Grover et al. (1977). The reaction mixture consists of $1.4 \mathrm{~mL}$ of $0.1 \mathrm{M}$ sodium acetate buffer ( $\mathrm{pH} 5.0$ ), $0.1 \mathrm{~mL}$ of crude enzyme with $0.5 \mathrm{~mL}$ of $0.02 \mathrm{M} p$-nitrophenyl- $\beta$-D-glucopyranoside (pNPG) and incubated for $15 \mathrm{~min}$ at $37{ }^{\circ} \mathrm{C}$. The enzyme reaction was stopped by the addition of $2.0 \mathrm{~mL} 0.2 \mathrm{M}$ sodium carbonate and absorbance was measured at $400 \mathrm{~nm}$. Enzyme activity was measured in international units (IU) per $\mathrm{mL}$. The amount of enzyme required to liberate $1 \mu \mathrm{mol}$ of glucose, xylose, or $p$-nitrophenol from their respective substrates per min under the assay conditions was defined as 1 IU of enzyme activity (Kovács et al. 2009).

\section{Thermostability assay}

The effect of temperature on enzymes activity was determined by incubating crude enzyme at different temperatures ranging from 30 to $80^{\circ} \mathrm{C}$ at the various time intervals. After incubation, the activity of the enzymes was determined by the standard assay as described earlier.

\section{Results and discussion}

In the current study, fifteen thermophilic fungi were isolated from soil based on their ability to grow at high temperatures. Fungal identification was performed using $18 \mathrm{~S}$ rRNA sequencing (Table 1 ).

\section{Screening of cellulase and xylanase activity}

Fifteen thermophilic fungal isolates from soil samples were screened for cellulase and xylanase activity on Czapek-Dox medium containing CMC or beechwood as a substrate. Cellulolytic fungal strains were selected based on the diameter of hydrolysis zones surrounding the colonies. Detection of extracellular hydrolytic enzyme activity was performed using qualitative evaluation of Congo red staining (Meddeb-Mouelhi et al. 2014). Cellulase and xylanase activities were measured using the enzyme activity index by measuring the clearance zone surrounding the colonies (Figs. 1, 2). Fungal isolates with high EI values were considered to be potential cellulase and xylanase producers. Of the fifteen isolated fungi, A. fumigatus JCM 10253 and Aspergillus terreus exhibited the highest cellulase activity with EI values of 1.50 and 1.24, respectively, followed by Aspergillus sp. (EI 1.13), Fusarium verticillioides (EI 1.11), and Eurotium rubrum (EI 1.09). However, the hydrolytic activity of other isolates,

Table 1 List of the selected fungal strains isolated from soil source and its observation after temperature drift

\begin{tabular}{|c|c|c|c|c|}
\hline \multirow[t]{2}{*}{ Accession no. } & \multirow[t]{2}{*}{ Fungal strains } & \multicolumn{3}{|l|}{ Temperature drift } \\
\hline & & $\begin{array}{l}30{ }^{\circ} \mathrm{C} \\
\text { Colony diameter }(\mathrm{cm})\end{array}$ & $\begin{array}{l}40^{\circ} \mathrm{C} \\
\text { Colony diameter }(\mathrm{cm})\end{array}$ & $\begin{array}{l}50{ }^{\circ} \mathrm{C} \\
\text { Colony diameter }(\mathrm{cm})\end{array}$ \\
\hline MF967277 & Aspergillus caespitosus & $4.40 \pm 0.16$ & $5.80 \pm 0.01$ & $6.10 \pm 0.02$ \\
\hline MF319901 & Aspergillus flavus & $4.50 \pm 0.02$ & $5.90 \pm 0.05$ & $6.20 \pm 0.02$ \\
\hline LC228711 & Aspergillus fumigatus JCM 10253 & $5.40 \pm 0.13$ & $6.20 \pm 0.01$ & $6.50 \pm 0.14$ \\
\hline MF319894 & Aspergillus nidulans & $5.20 \pm 0.09$ & $6.10 \pm 0.16$ & $6.60 \pm 0.19$ \\
\hline MF319897 & Aspergillus nomius & $5.10 \pm 0.04$ & $6.80 \pm 0.13$ & $7.40 \pm 0.05$ \\
\hline DQ087531 & Aspergillus ochraceus & $5.90 \pm 0.02$ & $6.30 \pm 0.02$ & $7.10 \pm 0.01$ \\
\hline KY425742 & Aspergillus oryzae & $5.10 \pm 0.12$ & $5.80 \pm 0.02$ & $6.50 \pm 0.01$ \\
\hline KU504333 & Aspergillus sp. & $5.50 \pm 0.04$ & $6.10 \pm 0.14$ & $7.30 \pm 0.02$ \\
\hline AY864861 & Aspergillus terreus & $4.30 \pm 0.02$ & $5.20 \pm 0.01$ & $6.10 \pm 0.01$ \\
\hline HM116370 & Eurotium rubrum & $4.80 \pm 0.09$ & $5.70 \pm 0.05$ & $6.20 \pm 0.16$ \\
\hline DQ491422 & Fomitopsis africana & $4.60 \pm 0.01$ & $5.80 \pm 0.03$ & $6.50 \pm 0.11$ \\
\hline KJ670294 & Fomitopsis sp. & $5.30 \pm 0.17$ & $6.20 \pm 0.01$ & $6.80 \pm 0.01$ \\
\hline KR052812 & Fusarium verticillioides & $4.90 \pm 0.03$ & $5.90 \pm 0.13$ & $6.50 \pm 0.01$ \\
\hline MF319892 & Pleurotus pulmonarius & $5.60 \pm 0.05$ & $6.30 \pm 0.17$ & $6.80 \pm 0.03$ \\
\hline KU571484 & Rhizopus species & $4.50 \pm 0.18$ & $5.80 \pm 0.01$ & $6.20 \pm 0.02$ \\
\hline
\end{tabular}




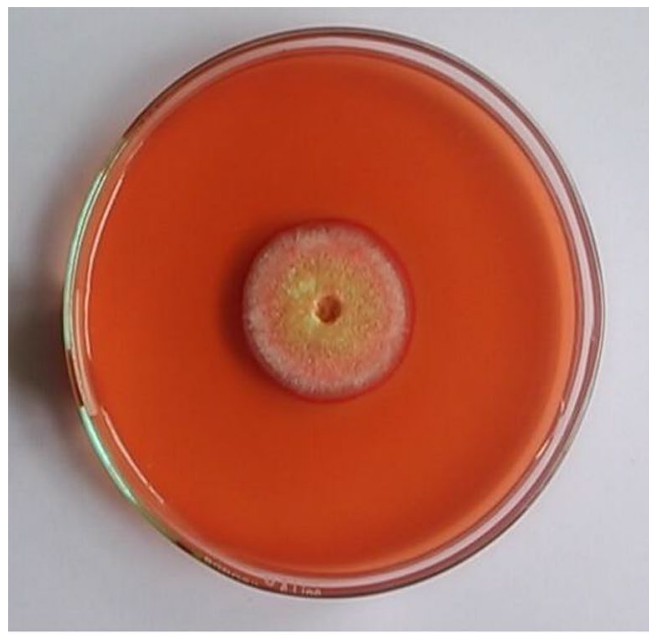

a

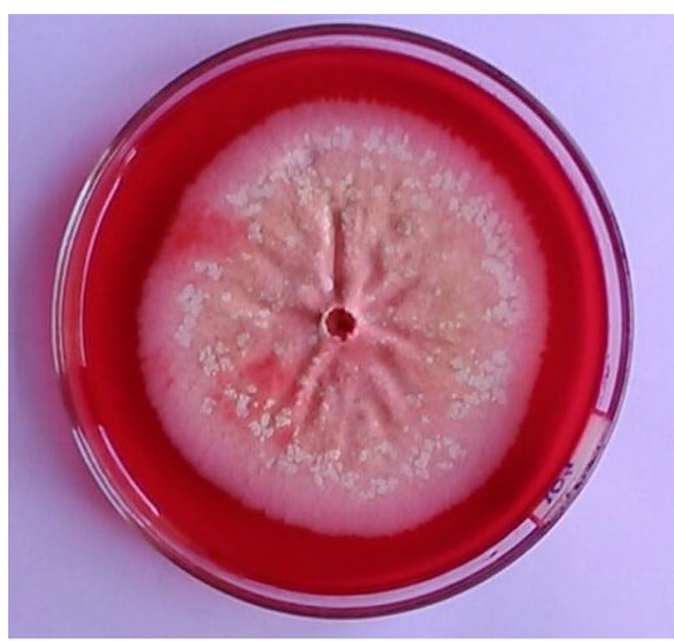

b

Fig. 1 Detection of cellulase activity from the isolated fungal strain on agar plates. Plates showing the zone of hydrolysis by Aspergillus fumigatus JCM 10253 with Congo red staining on the 7th day. a Plate without CMC; $\mathbf{b}$ plate with CMC as a substrate

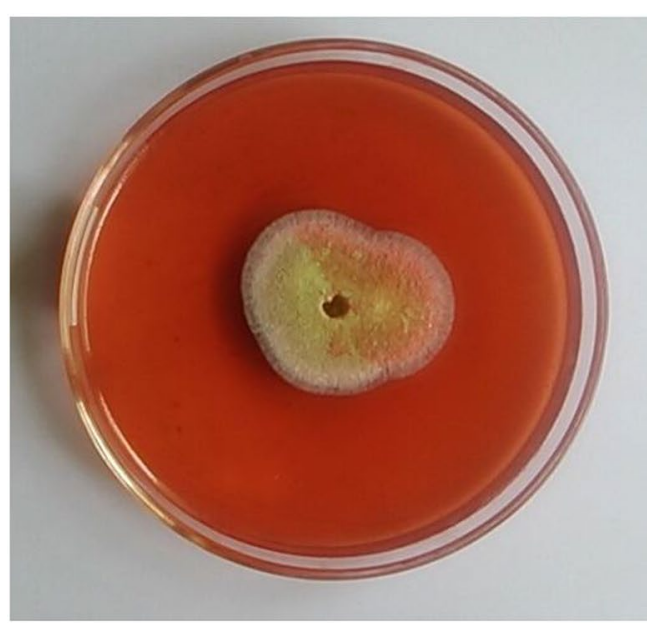

a

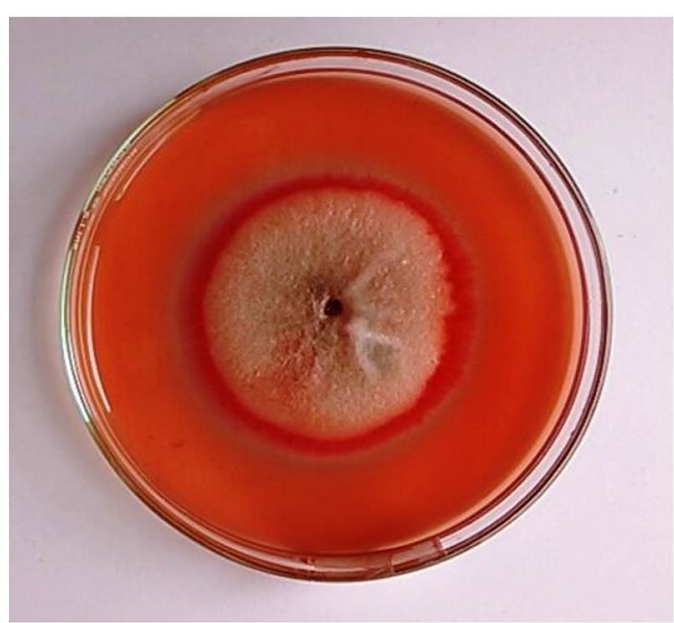

b

Fig. 2 Detection of xylanase activity from the isolated fungal strain on agar plates. Plates showing the zone of hydrolysis by Aspergillus fumigatus JCM 10253 with Congo red staining on the 7th day. a Plate without xylan; $\mathbf{b}$ plate with xylan as a substrate

including Aspergillus caespitosus (EI 1.05), Aspergillus oryzae (EI 1.05), Rhizopus sp. (EI 1.05), Aspergillus nidulans (EI 1.03), Aspergillus nomius (EI 1.03), Fomitopsis africana (EI 1.03), Fomitopsis sp. (EI 1.03), Pleurotus pulmonarius (EI 1.03), Aspergillus flavus (EI 1.02), and Aspergillus ochraceus (EI 1.02), was relatively low. Moreover, none of the fungal isolates were resistant to CMC agar and the colony growth of fungal isolates on CMC agar was greater than that on control agar (Table 2). In agreement with these results, Aspergillus sp. has been reported to possess all of the necessary components of the cellulase enzyme system (de Vries and Visser 2001; Khokhar et al. 2012).

The most efficient xylanase (endo-1,4- $\beta$-Dxylanohydrolase) producing strains were selected based on the size of the clearance zone surrounding the fungal colonies. A. fumigatus JCM 10253 (EI 1.18) and F. verticillioides (EI 1.09) exhibited the highest xylanase activities followed by E. rubrum (EI 1.08), F. africana (EI 1.08), Aspergillus sp. (EI 1.03), A. nomius (EI 1.03), P. pulmonarius (EI 1.03), and A.terreus (EI 1.02). Other isolated fungal strains, including $A$. oryzae (EI 1.01), A. caespitosus 


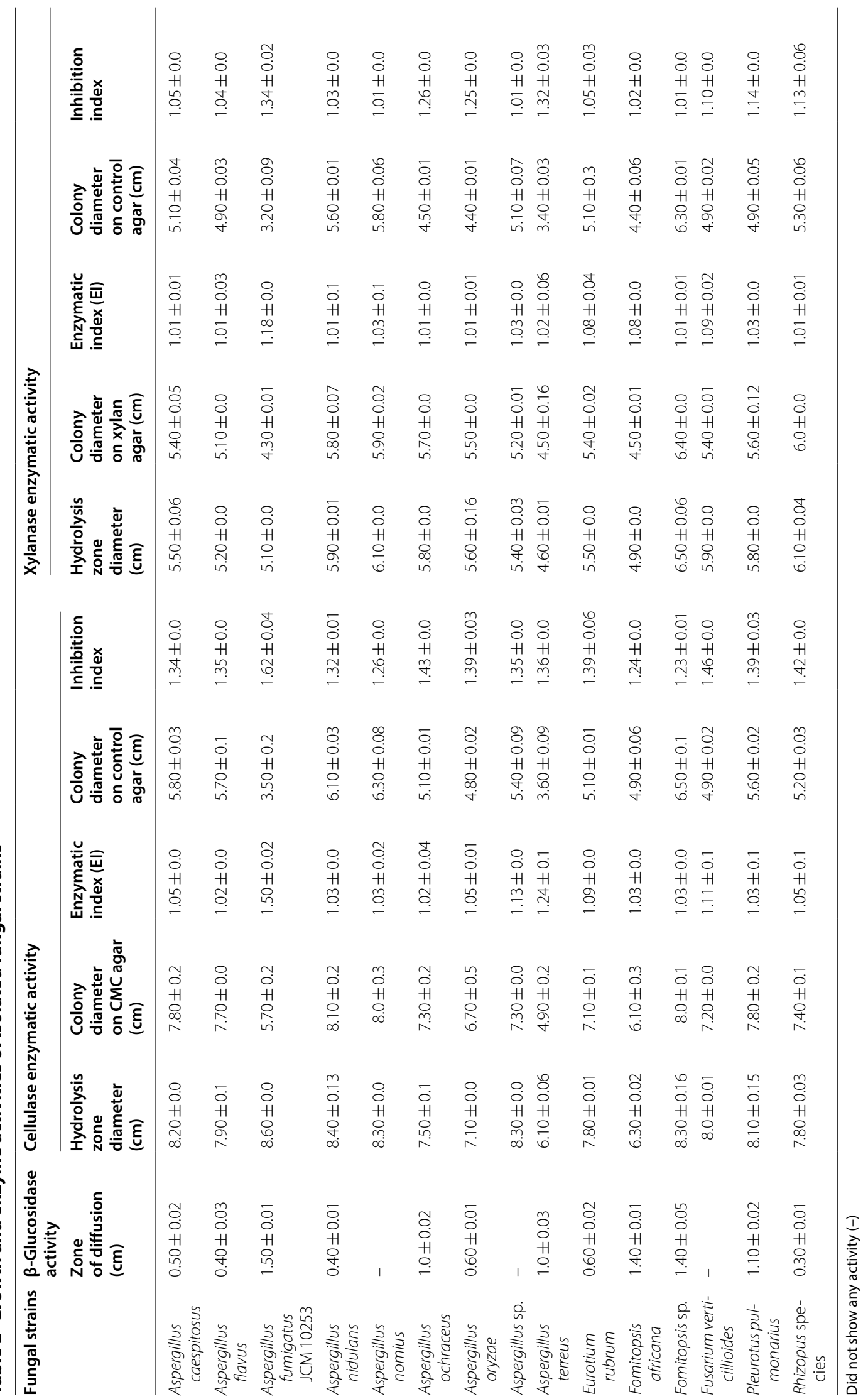


(EI 1.01), A. ochraceus (EI 1.01), A. nidulans (EI 1.01), A. flavus (EI 1.01), Fomitopsis sp. (EI 1.01) and Rhizopus sp. (EI 1.01) exhibited relatively low xylanase activity when grown on xylan agar. Moreover, the colony growth of all isolated fungal strains on xylan agar was found to be slightly higher than on control agar (Table 2). Hence, the fungal isolates were found non-resistant towards xylan agar, as the colony growth on xylan agar was slightly higher than control.

The growth simulation/inhibition index was estimated by the ratio of the diameter of colonies on CMC or xylan agar to the diameter of the colonies on control agar. The index value represents the activity of each enzyme; an index value $<1$ indicates substrate-inhibited fungal growth, whereas an index value $>1$ indicates substrateinduced growth stimulation. Based on the inhibition indices for cellulase, the growth of $A$. fumigatus JCM 10253 (1.62), F. verticillioides (1.46), A. ochraceus (1.43) and Rhizopus sp. (1.42) was enhanced by CMC agar medium, whereas the effect of CMC agar medium was slightly reduced for the other isolates. On the other hand, based on the inhibition indices, the growth of the xylanase-producing fungal strains A. fumigatus JCM 10253 (1.34), A. terreus (1.32), A. ochraceus (1.26) and A. oryzae (1.25) was enhanced by xylan medium, whereas the effect of xylan was slightly reduced for the other isolates.

The most commonly used microbes for the production of hydrolytic enzymes belong to the genera Aspergillus, Trichoderma, and Penicillium (Yadav 2017). Previous reports showed that soft rot fungi, such as Aspergillus niger and Trichoderma reesei (Xue et al. 2017), and the white rot fungus Phanerochaete chrysosporium produce large amounts of cellulase (Manavalan et al. 2015). A recent study showed that some of the white rot fungi are the most promising fungi in terms of biomass degradation and delignification because of their potential to synthesize cellulolytic, hemicellulolytic, and ligninolytic enzymes (Xu et al. 2018). Hydrolysis zone diameter was correlated with colony diameter on CMC and xylan agar media. However, the hydrolytic activity of all the isolates was found to be slightly higher. The hydrolytic activity of all isolates was found to be $<1$. A. fumigatus JCM 10253 exhibited the highest hydrolytic activity, whereas the hydrolytic activity of the other isolates was slightly lower. The difference between isolates was statistically significant $(p \leq 0.05)$. The method used to screen for hydrolytic enzyme-producing fungi has previously been reported and found to be suitable (Abdel-Sater and El-Said 2001; Lalita and Prasher 2014; Bairagi 2016).

\section{Screening of $\beta$-glucosidase activity by gel diffusion plate} assay

Fungal isolates were deemed to be positive for $\beta$-glucosidase activity based on the appearance a black zone caused by the reaction between esculetin (6,7-dihydroxycoumarin) and ferric ion (Veena et al. 2011). Esculin is a glycoside, which is a naturally occurring sugar derivative. Glycosidase enzymes catalyze the hydrolysis of glycosides into sugars and non-sugars that can be used as a fuel resource for energy production. The presence of $\beta$-glucosidase causes the hydrolysis of esculin, producing a glucose molecule and the aglycone component esculetin. The non-sugar component aglycone can be used to assess the presence of glycosidase (Ford 2014), as it is the aglycone that reacts with ferric ions, resulting in the formation of a black chelate compound. Thus, the hydrolysis of the glycosidic bond by $\beta$-glycosidase via a hydrolytic reaction, resulting in the formation of an iron complex, is the key to the identification of enzyme activity. The reaction of esculetin with $\mathrm{Fe}^{+3}$ or ferric salts is a highly sensitive method due to the intensity of the color and the ease of identification (Edberg et al. 1985). The use of esculin with ferric chloride is a proven zymographic technique for the screening of $\beta$-glucosidase that is both cost-effective and gives distinct results (Kwon et al. 1994). In the present study, $16 \mu \mathrm{L}$ of fungal culture filtrate was inoculated onto esculin agar plates and incubated at $37{ }^{\circ} \mathrm{C}$ for $5 \mathrm{~h}$. Different incubation periods between 2 and $5 \mathrm{~h}$ did not result in any significant changes in the diameter of the zone of diffusion. Therefore, a 2 -h incubation period is sufficient for the gel diffusion assay. The black zone of diffusion was compared to the standard curve of almond $\beta$-glucosidase (EC 3.2.1.21; activity $\geq 10 \mathrm{U} / \mathrm{mg}$ solid; Fig. 3).

Table 2 shows the fungal activity of the fifteen isolates determined by gel diffusion plate assays. The zone of diffusion was largest for A. fumigatus JCM 10253 (4 mg/ $\mathrm{mL} ; 1.5 \mathrm{~cm}$ ) followed by F. africana and Fomitopsis sp. $(2 \mathrm{mg} / \mathrm{mL} ; 1.4 \mathrm{~cm})$, P. pulmonarius $(1.1 \mathrm{~cm})$, A. ochraceus $(1.0 \mathrm{~cm})$, E. rubrum $(0.6 \mathrm{~cm})$, and $A$. caespitosus $(0.5 \mathrm{~cm})$. These results indicate that these fungi exhibit $\beta$-glucosidase activity and esculin hydrolysis. In contrast, no zone of diffusion was visible when A. nomius, Aspergillus sp., or $F$. verticillioides were inoculated on esculin gel. The absence of a black zone clearly indicates that these fungal strains do not have the ability to hydrolyze esculin. It has been previously reported that the diameter of the diffusion zone in a gel diffusion assay is proportional to the enzyme concentration (Wood et al. 1988; 


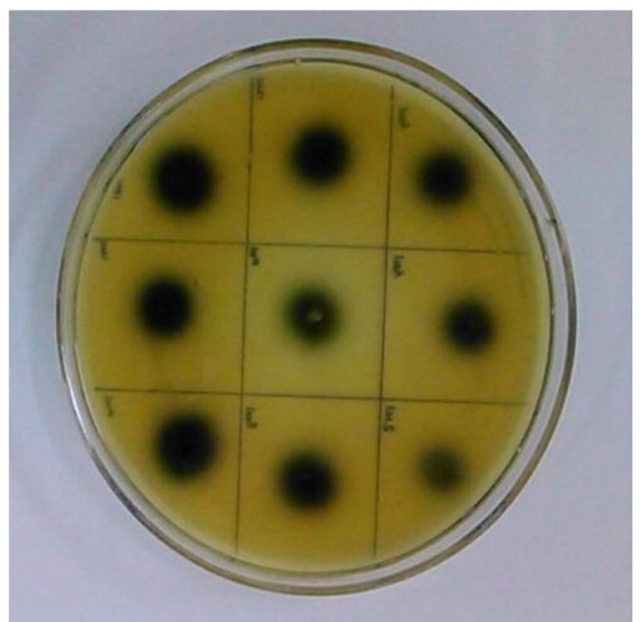

a

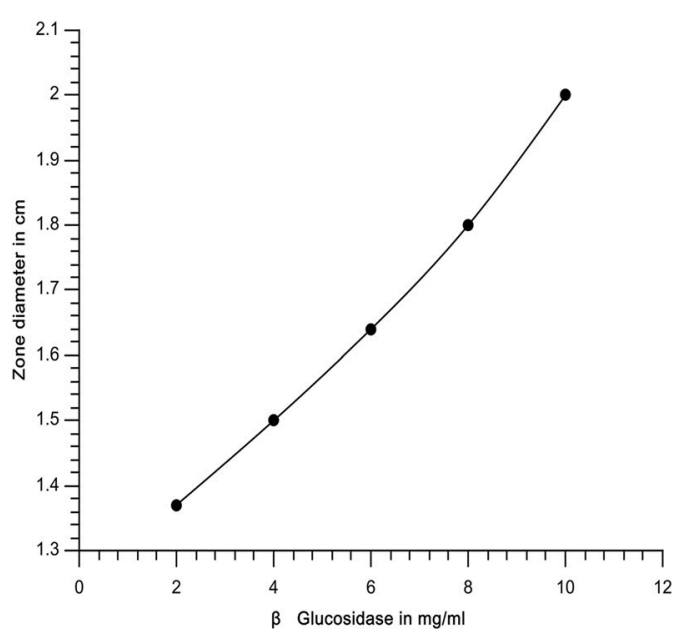

b

Fig. 3 Standard curve on esculin gel diffusion assay for $\beta$-glucosidase. a Different concentrations of standard $\beta$-glucosidase enzyme from sweet almond (EC 3.2.1.21; activity: $\geq 10 \mathrm{U} / \mathrm{mg}$ solid procured from Himedia) activity on EGDA plate, $\mathbf{b}$ standard curve of enzyme activity

Saqib and Whitney 2006). Therefore, a standard curve of $\beta$-glucosidase was prepared on esculin gel to confirm this correlation.

\section{Plate assay for lignin degradation and laccase activity}

A lignin degradation plate assay was performed to assess clearance zones by staining the fungal agar plates with a $1 \% \mathrm{w} / \mathrm{v}$ aqueous solution of $\mathrm{FeCl}_{3}$ and $\mathrm{K}_{3}\left[\mathrm{Fe}(\mathrm{CN})_{6}\right]$, as shown in Fig. 4. After staining, oxidized phenolic components appear blue-green with a clear zone around the colonies (Pointing 1999; Ali and Muid 2012). The clearance zone of lignin degradation for each of the fungal strains is shown in Table 3. A. ochraceus exhibited the largest clearance zone around the colonies $(5.5 \mathrm{~cm})$ followed by Rhizopus sp. $(3.9 \mathrm{~cm}), F$. africana $(3.8 \mathrm{~cm}), F$. verticillioides $(3.5 \mathrm{~cm})$, A. nomius $(3.3 \mathrm{~cm})$ and A. flavus $(3.2 \mathrm{~cm})$. P. pulmonarius and Fomitopsis sp. exhibited smaller clearance zones than the other isolates.

Fungal isolates were further screened for their ability to secrete extracellular laccase using guaiacol as a phenolic substrate. Extracellular laccase is constitutively produced in small amounts by basidiomycete

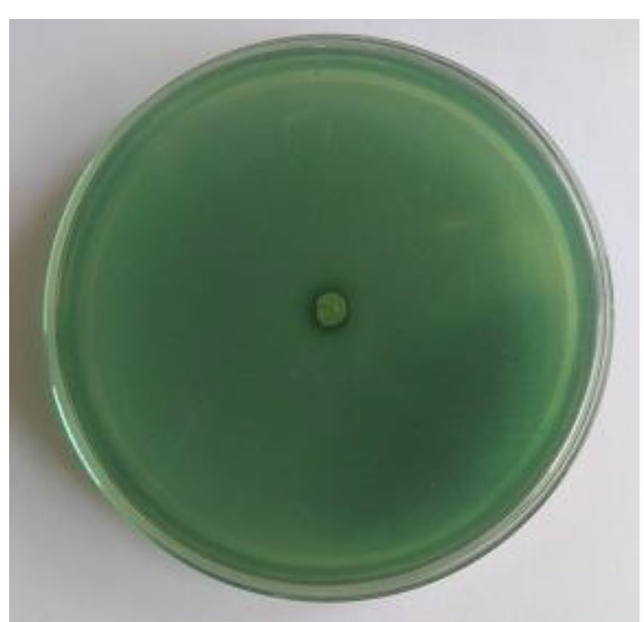

a

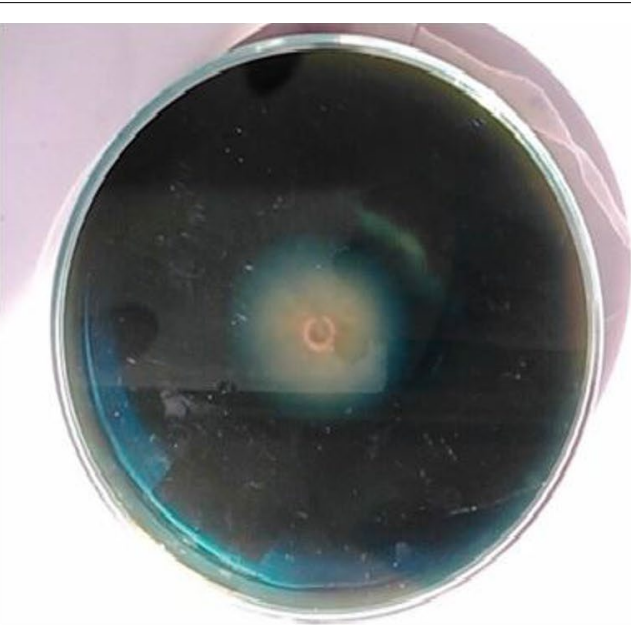

b

Fig. 4 Detection of lignin degradation activity from the isolated fungal strain on agar plates. Plates showing the zone of clearance by Aspergillus fumigatus JCM 10253 with staining with $1 \%$ of $\mathrm{FeCl}_{3}$ and $\mathrm{K}_{3}\left[\mathrm{Fe}(\mathrm{CN})_{6}\right]$ on the 7 th day. a Plate without lignin; $\mathbf{b}$ plate with lignin as a substrate 
Table 3 Summary of plate assay method for lignin degradation and laccase activity of fungal isolates on the 7th day

\begin{tabular}{lll}
\hline Fungal strains & $\begin{array}{l}\text { Lignin } \\
\text { degradation } \\
\text { activity } \\
\text { Zone } \\
\text { of degradation } \\
\text { (cm) }\end{array}$ & $\begin{array}{l}\text { Laccase activity } \\
\text { Zone of growth (cm) }\end{array}$ \\
\hline Aspergillus caespitosus & $2.50 \pm 0.04$ & $2.50 \pm 0.01$ \\
Aspergillus flavus & $3.20 \pm 0.01$ & $3.10 \pm 0.02$ \\
Aspergillus fumigatus JCM & $3.10 \pm 0.02$ & $3.30 \pm 0.01$ \\
$\quad$ 10253 & $2.40 \pm 0.01$ & $2.80 \pm 0.09$ \\
Aspergillus nidulans & $3.30 \pm 0.07$ & $4.20 \pm 0.02$ \\
Aspergillus nomius & $5.50 \pm 0.03$ & $3.50 \pm 0.12$ \\
Aspergillus ochraceus & $3.10 \pm 0.02$ & $3.00 \pm 0.01$ \\
Aspergillus oryzae & $2.50 \pm 0.09$ & $2.50 \pm 0.17$ \\
Aspergillus sp. & $3.30 \pm 0.02$ & $3.30 \pm 0.04$ \\
Aspergillus terreus & $2.50 \pm 0.01$ & $2.50 \pm 0.02$ \\
Eurotium rubrum & $3.80 \pm 0.01$ & $3.80 \pm 0.16$ \\
Fomitopsis africana & $2.10 \pm 0.01$ & $2.70 \pm 0.01$ \\
Fomitopsis sp. & $3.50 \pm 0.06$ & $4.30 \pm 0.03$ \\
Fusarium verticillioides & $1.90 \pm 0.03$ & $4.50 \pm 0.02$ \\
Pleurotus pulmonarius & $3.90 \pm 0.01$ & $3.30 \pm 0.01$ \\
Rhizopus species & & \\
\hline
\end{tabular}

fungi, particularly wild-type strains of white rod fungi such as Pleurotus ostreatus (Hou et al. 2004), Funalia trogii (Birhanli and Yesilada 2006), and Trametes pubescens (Galhaup et al. 2002). The formation of a reddish brown color on solid media when guaiacol is used as the substrate is an indication of extracellular laccase production by filamentous fungi (Thurston 1994; Madhavi and Lele 2009). In this study, the appearance of a reddish brown color due to the redox reaction was used to indicate laccase secretion (Fig. 5). All isolates were shown to be positive and diameter of the zone was measured for their potential laccase activity, as shown in Table 3 . The growth diameter of $P$. pulmonarius $(4.5 \mathrm{~cm}), F$. verticillioides $(4.3 \mathrm{~cm})$, and $A$. nomius $(4.2 \mathrm{~cm})$ was highest on guaiacol-containing agar plates. A. caespitosus, Aspergillus sp., and E. rubrum exhibited the lowest activity. The extracellular laccase formation observed in the present study is in agreement with previous studies of various fungal strains carried out by Revankar and Lele (2006) and Fu et al. (2013). Table 4 shows the qualitative assessment of lignocellulolytic enzymes produced by plate assay methods.

\section{Enzyme production}

Aspergillus fumigatus strain JCM 10253 was used for hydrolytic enzyme production by solid-state fermentation. Solid-state fermentation system provides an intrinsic state which is suitable for growing filamentous fungi to produce cellulases and xylanase (Singhania et al. 2010). In the present study, maximum CMCase $(26.2 \mathrm{IU} / \mathrm{mL})$ and FPase $(18.2 \mathrm{IU} / \mathrm{mL})$ activity was observed at $144 \mathrm{~h}$, whereas maximum $\beta$-glucosidase $(0.87 \mathrm{IU} / \mathrm{mL})$ and xylanase $(2.6 \mathrm{IU} / \mathrm{mL})$ activity was observed after $192 \mathrm{~h}$ of incubation time at $50{ }^{\circ} \mathrm{C}$ (Fig. 6). However, in the present study, $\beta$-glucosidase activity remained relatively low and the longer incubation period caused a decline in enzyme production. This may be due to the depletion of nutrients

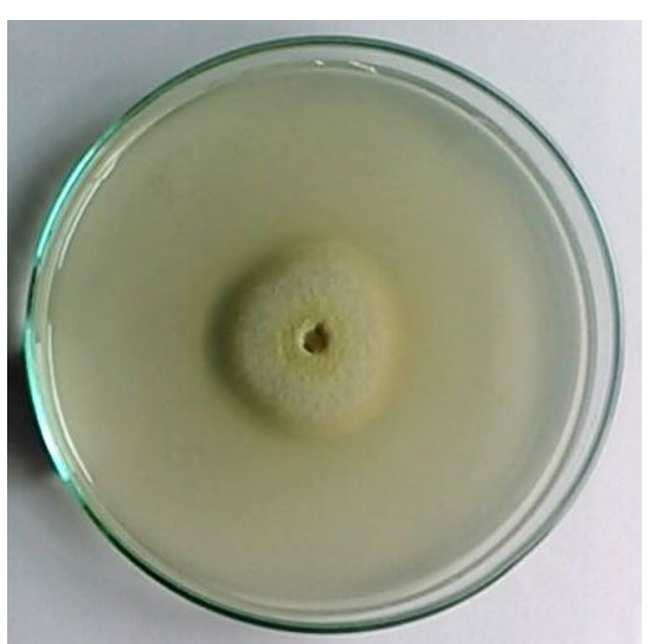

a

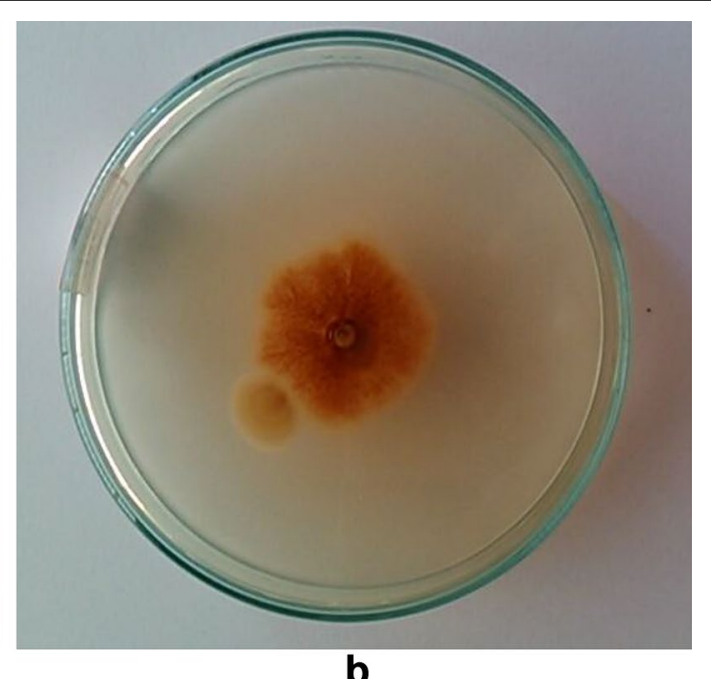

b

Fig. 5 Detection of laccase enzyme activity from the isolated fungal strain on agar plates. The appearance of the reddish brown zone around the colony indicates as a laccase-producing fungal strain on the 7th day. a Plate without guaiacol; b plate with guaiacol as a substrate 
Table 4 Qualitative estimation of lignocellulolytic enzymes by plate assay methods

\begin{tabular}{|c|c|c|c|c|c|}
\hline Fungal strains & $\begin{array}{l}\beta \text {-Glucosidase } \\
\text { activity }\end{array}$ & Cellulase activity & Xylanase activity & $\begin{array}{l}\text { Lignin } \\
\text { degradation } \\
\text { activity }\end{array}$ & Laccase activity \\
\hline Aspergillus caespitosus & + & ++ & ++ & + & + \\
\hline Aspergillus flavus & + & ++ & ++ & ++ & ++ \\
\hline Aspergillus fumigatus JCM 10253 & +++ & +++ & +++ & ++ & ++ \\
\hline Aspergillus nidulans & + & ++ & ++ & + & + \\
\hline Aspergillus nomius & - & ++ & ++ & ++ & +++ \\
\hline Aspergillus ochraceus & ++ & ++ & ++ & +++ & ++ \\
\hline Aspergillus oryzae & + & ++ & ++ & ++ & ++ \\
\hline Aspergillus sp. & - & ++ & ++ & + & + \\
\hline Aspergillus terreus & ++ & +++ & ++ & ++ & ++ \\
\hline Eurotium rubrum & + & ++ & ++ & + & + \\
\hline Fomitopsis africana & +++ & ++ & ++ & +++ & ++ \\
\hline Fomitopsis sp. & +++ & ++ & ++ & + & + \\
\hline Fusarium verticillioides & - & ++ & +++ & ++ & +++ \\
\hline Pleurotus pulmonarius & ++ & ++ & ++ & + & +++ \\
\hline Rhizopus species & + & ++ & ++ & +++ & ++ \\
\hline
\end{tabular}

$(-=$ no activity,$+=$ minimum,$++=$ medium,$+++=$ maximum activity $)$

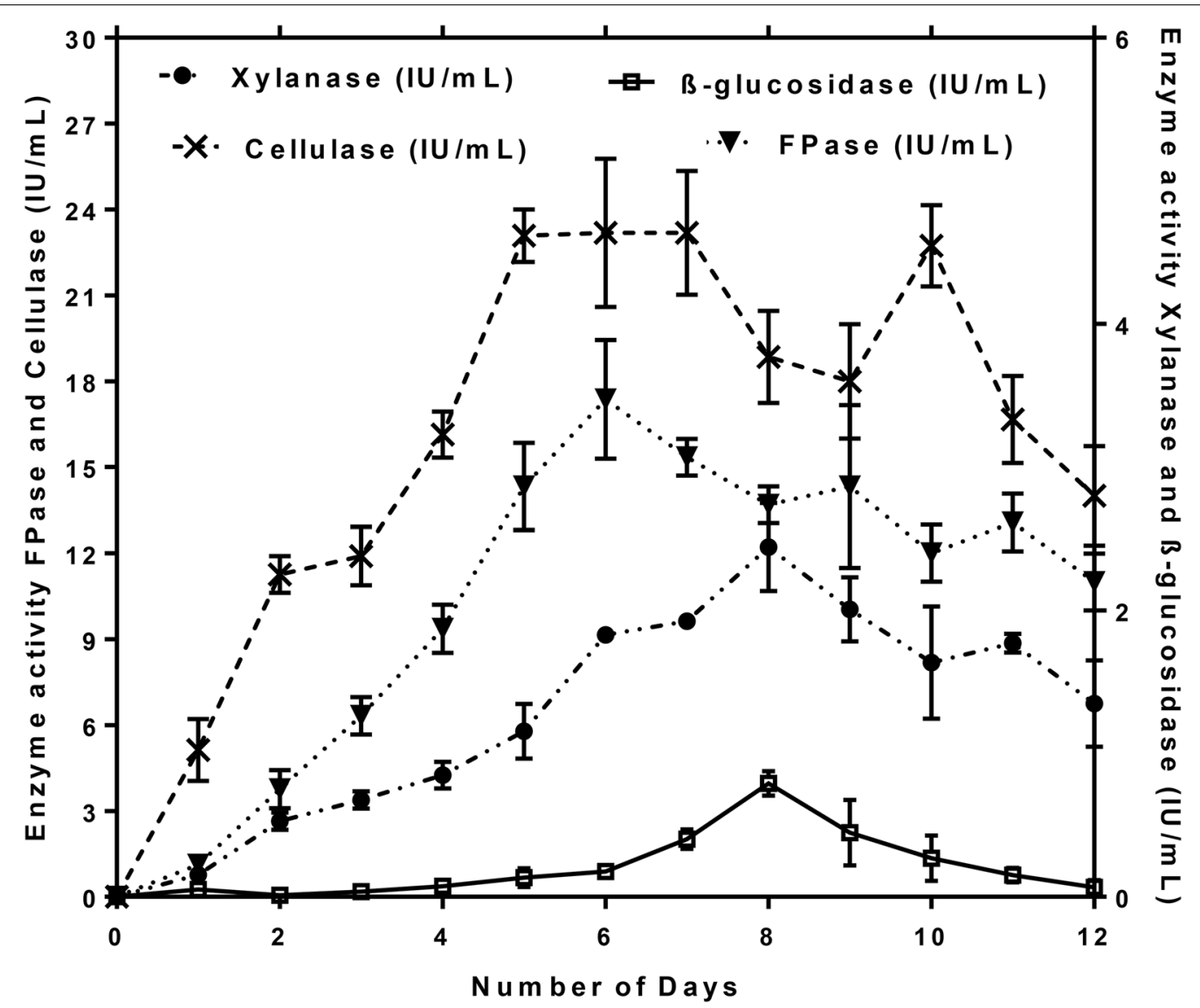

Fig. 6 Profiles of cellulases and xylanase produced by Aspergillus fumigatus JCM 10253 in SSF using wheat bran as a substrate 
or the spontaneous denaturation of the enzyme (Sandhya et al. 2005). Solid-state fermentation is a well-established technology for enzyme production and has various advantages, such as low costs of operation and the ability to use agro-industrial residues as the raw material (Raimbault 1998; Pandey et al. 2000; Adsul et al. 2014). Enzyme production also depends on various factors, such as chemical composition, accessibility, and the physiochemical links between the components of the substrate (Gao et al. 2008).

\section{Comparative studies}

Previous studies on Aspergillus sp. in the production of cellulase and hemicellulase as summarized in Table 5 . In the present study, A. fumigatus strain JCM 10253 produced hydrolytic enzymes with higher activity as compared to previous studies. The maximum CMCase $(26.2 \mathrm{IU} / \mathrm{mL}), \quad$ FPase $(18.2 \mathrm{IU} / \mathrm{mL}), \quad \beta$-glucosidase $(0.87 \mathrm{IU} / \mathrm{mL})$, and xylanase $(2.6 \mathrm{IU} / \mathrm{mL})$ activities were obtained. In previous reports, A. fumigatus SK1 showed CMCase $(54.3 \mathrm{U} / \mathrm{g})$, FPase $(3.35 \mathrm{U} / \mathrm{g}), \beta$-glucosidase $(4.5 \mathrm{U} / \mathrm{g})$ and xylanase $(418.7 \mathrm{U} / \mathrm{g})$ activities using oil palm trunk as a substrate (Ang et al. 2013). On the other hand, A. fumigatus SK1 cellulase activity was 1.4-fold higher compared to A. fumigatus MS16 and xylanase activity was 2.7 -fold high as compared to A. niger MS80 (Sohail et al. 2009; Ang et al. 2013). Grigorevski-Lima et al. (2009) obtained $365 \mathrm{U} \mathrm{L}^{-1}$ activity of endoglucanase (CMCase) from A. fumigatus at temperature $65{ }^{\circ} \mathrm{C}$ and $\mathrm{pH}$ 2. It has been reported that Aspergillus sp. is categorized as intense xylanase producer (Polizeli et al. 2005; Sohail et al. 2009; Ibrahim 2008). Hence, A. fumigatus
JCM 10253 showed higher xylanase activity as compared to $A$. niger MS 80 .

\section{Thermostability studies}

The activity of crude enzymes from A. fumigatus JCM 10253 was investigated at various temperatures ranging from 30 to $80{ }^{\circ} \mathrm{C}$ in an attempt to understand the effects of temperature on the enzyme activity. The temperature profile demonstrated the optimum temperature for CMCase, FPase, $\beta$-glucosidase, and xylanase. The $\mathrm{CMCase}$ showed optimum activity at $60{ }^{\circ} \mathrm{C}$ and FPase, $\beta$-glucosidase, and xylanase exhibited optimum activity at $50{ }^{\circ} \mathrm{C}$ as shown in Fig. 7a. Hence, declining in enzyme activity with the further increase in temperature could be due to denaturation by heat (Olajuyigbe et al. 2016). Figure $7 \mathrm{~b}$ depicts the crude cellulase retained $80 \%$ of its initial activity in first $20 \mathrm{~min}$ of incubation at $60^{\circ} \mathrm{C}$, but this gradually decreased in the next $40 \mathrm{~min}$, providing a maximum of $65-70 \%$ activity after $40 \mathrm{~min}$. $\beta$-Glucosidase and FPase retained $80-90 \%$ of their activities in first $120 \mathrm{~min}$ of incubation at $40-50{ }^{\circ} \mathrm{C}$. However, there was a decline in the activity at a higher temperature (Fig. 7c, d). Xylanase enzyme retained about $95 \%$ activity of its initial activity in the first $20 \mathrm{~min}$ of incubation at $30-50{ }^{\circ} \mathrm{C}$, whereas it decreases to $75 \%$ with the increase in the incubation time period. Increase in temperature showed lower stability retaining about $30-60 \%$ activity (Fig. 7e).

\section{Concluding remarks}

Thermophilic fungi are known to produce industrially important lignocellulolytic enzymes which play a significant role in degradation processes of lignocellulosic

Table 5 Comparison of cellulases and xylanase produced by Aspergillus sp. with different substrates

\begin{tabular}{|c|c|c|c|c|c|c|c|}
\hline \multirow[t]{2}{*}{ Organisms } & \multirow{2}{*}{$\begin{array}{l}\text { Type } \\
\text { of reactor }\end{array}$} & \multirow[t]{2}{*}{ Substrate } & \multicolumn{4}{|c|}{ Enzyme activities } & \multirow[t]{2}{*}{ References } \\
\hline & & & CMCase & FPase & $\beta$-Glucosidase & Xylanase & \\
\hline $\begin{array}{l}\text { Aspergillus fumigatus JCM } \\
10253\end{array}$ & Flask & Wheat bran & $26.2 \mathrm{U} / \mathrm{mL}$ & $18.2 \mathrm{U} / \mathrm{mL}$ & $0.87 \mathrm{U} / \mathrm{mL}$ & $2.6 \mathrm{U} / \mathrm{mL}$ & This study \\
\hline Aspergillus fumigatus SK1 & Flask & Oil palm trunk & $54.27 \mathrm{U} / \mathrm{g}$ & $3.35 \mathrm{U} / \mathrm{g}$ & $4.51 \mathrm{U} / \mathrm{g}$ & $418.70 \mathrm{U} / \mathrm{g}$ & Ang et al. (2013) \\
\hline Aspergillus fumigatus MS16 & Flask & CMC & $0.311 \mathrm{U} / \mathrm{mL}$ & - & $0.389 \mathrm{U} / \mathrm{mL}$ & - & Sohail et al. (2009) \\
\hline Aspergillus niger ATTC 6275 & Flask & Palm kernel cake & $23.80 \mathrm{U} / \mathrm{g}$ & - & - & $282.9 \mathrm{U} / \mathrm{g}$ & Prasertsan et al. (1992) \\
\hline Aspergillus niger EFB1 & $\begin{array}{l}\text { Rotary drum } \\
\text { reactor }\end{array}$ & $\begin{array}{l}\text { Oil palm empty fruit } \\
\text { bunch }\end{array}$ & $0.135 \mathrm{U} / \mathrm{mL}$ & $0.052 \mathrm{U} / \mathrm{mL}$ & $0.161 \mathrm{U} / \mathrm{mL}$ & - & Noratiqah et al. (2013) \\
\hline Aspergillus niger MS80 & Flask & Birchwood xylan & - & - & - & $1.24 \mathrm{U} / \mathrm{mL}$ & Sohail et al. (2009) \\
\hline Aspergillus fumigatus & Flask & Wheat straw & $16.9 \mathrm{U} / \mathrm{g}$ & $0.98 \mathrm{U} / \mathrm{g}$ & $11.80 \mathrm{U} / \mathrm{g}$ & $56.40 \mathrm{U} / \mathrm{g}$ & Sherief et al. (2010) \\
\hline Aspergillus terreus M11 & Flask & Corn stover & $581 \mathrm{U} / \mathrm{g}$ & $243 \mathrm{U} / \mathrm{g}$ & $128 \mathrm{U} / \mathrm{g}$ & - & Gao et al. (2008) \\
\hline Aspergillus fumigatus & Flask & Sweet sorghum & $26 \mathrm{U} / \mathrm{gds}$ & $3.9 \mathrm{U} / \mathrm{gds}$ & $6 \mathrm{U} / \mathrm{gds}$ & $1250 \mathrm{U} / \mathrm{gds}$ & $\begin{array}{l}\text { Bagewadi and Nin- } \\
\text { nekar (2015) }\end{array}$ \\
\hline
\end{tabular}




\section{a}

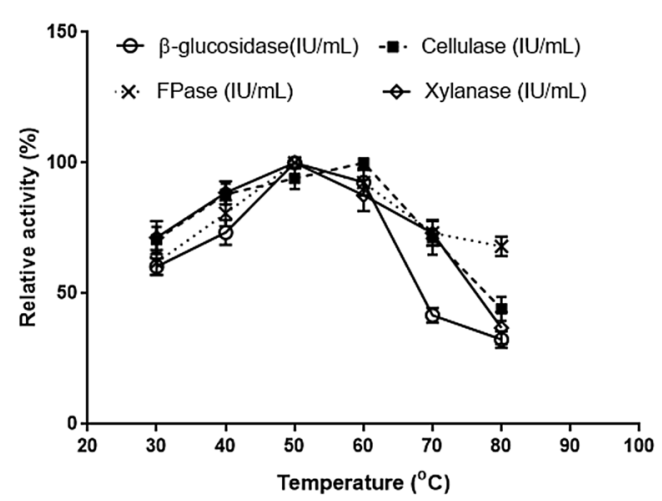

C

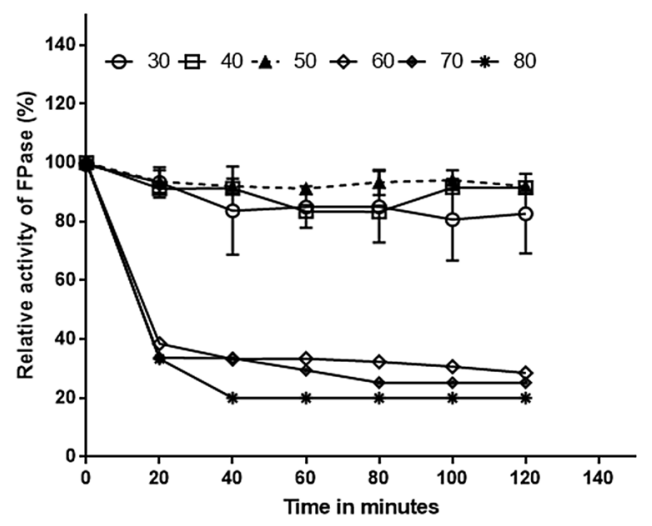

b

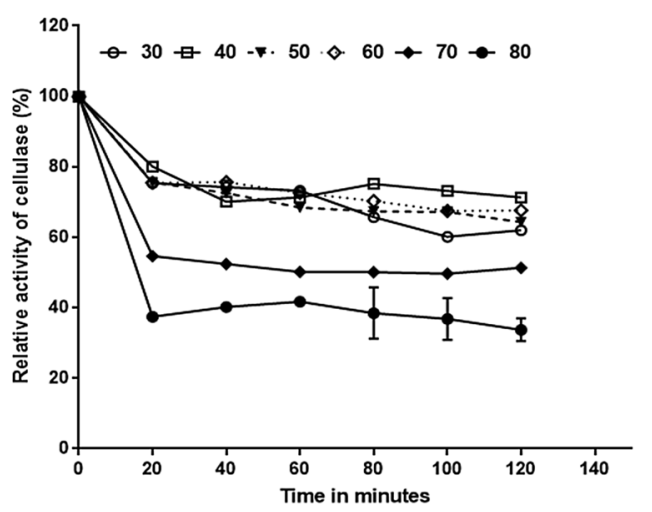

d

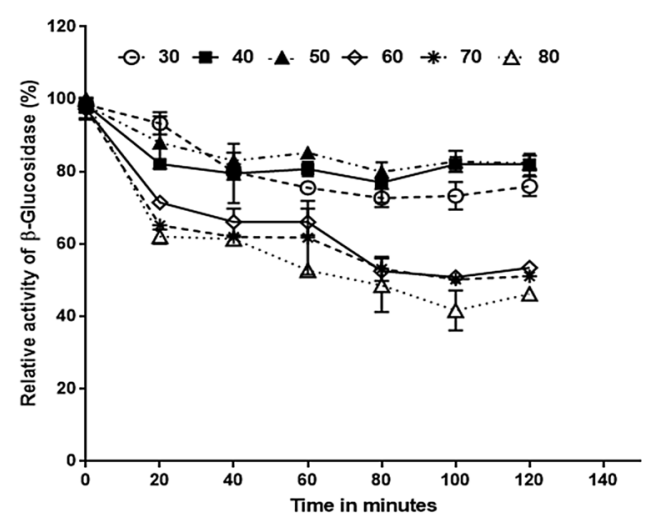

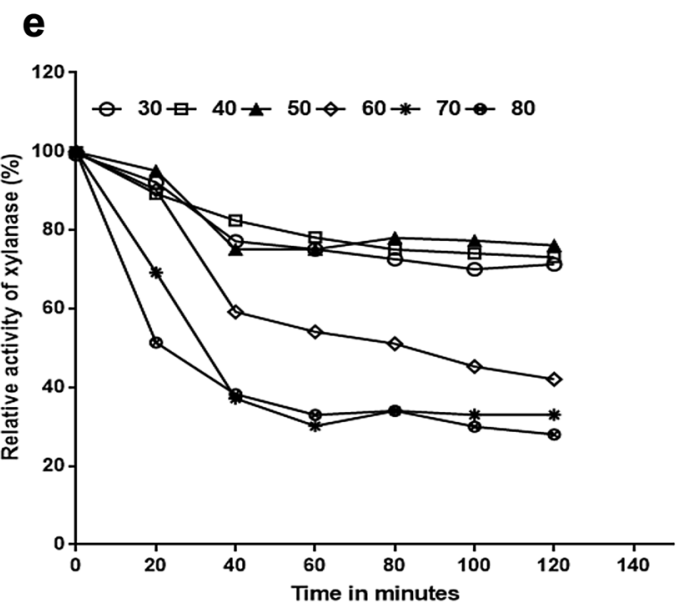

Fig. 7 Optimum temperature (a) and thermostability of crude CMCase (b), FPase (c), ß-glucosidase (d) and xylanase (e) of Aspergillus fumigatus JCM 10253

biomass, municipal solid waste, and other organic waste. In the present study, fifteen thermophilic fungi were isolated from the soil and most of them belonged to the Aspergillus genus. A. fumigatus JCM 10253 showed high cellulase activity and simultaneous esculin and xylose hydrolysis in plate assays. This suggests 
that thermophilic fungus is a producer of extracellular enzymes via lignocellulosic biomass degradation. Maximum CMCase $(26.2 \mathrm{IU} / \mathrm{mL})$, FPase $(18.2 \mathrm{IU} / \mathrm{mL})$, $\beta$-glucosidase $(0.87 \mathrm{IU} / \mathrm{mL})$, and xylanase $(2.6 \mathrm{IU} / \mathrm{mL})$ activity was obtained after incubation time of $144 \mathrm{~h}$ at $50{ }^{\circ} \mathrm{C}$ under solid-state fermentation. The thermostability of crude cellulase and xylanase showed optimum activities at 60 and $50^{\circ} \mathrm{C}$, respectively. This study represents an approach to scaling up studies in a bioreactor for commercial production to solve the problems associated with the bioconversion of lignocellulosic biomass into biofuels by selecting highly efficient producers of extracellular hydrolytic and ligninase enzymes.

\section{Abbreviations}

CMCase: Carboxymethyl cellulase; CMC: Carboxymethyl cellulose; DNS: 3,5-Dinitrosalicylic acid; EGDA: Esculin gel diffusion assay; El: Enzymatic index; FPase: Filter paper activity; IU: International units; MEA: Malt extract agar; SSF: Solid-state fermentation; UV: Ultra violet; YSS: Yeast soluble starch.

\section{Authors' contributions}

PS performed the research experiments and wrote the manuscript. MP helped in the experiments and manuscript writing. KN guided both authors during the experiments and manuscript preparation. All authors read and approved the final manuscript.

\section{Acknowledgements}

The authors acknowledge the support provided by the Department of Biotechnology, National Institute of Technology Warangal, Telangana, India.

\section{Competing interests}

The authors declare that they have no competing interests.

\section{Availability of data and materials}

All data generated or analyzed during this study are included in this article.

\section{Consent for publication}

Not applicable.

Ethics approval and consent to participate

Not applicable.

\section{Funding}

Not applicable.

\section{Publisher's Note}

Springer Nature remains neutral with regard to jurisdictional claims in published maps and institutional affiliations.

Received: 10 January 2018 Accepted: 18 June 2018

Published online: 10 July 2018

\section{References}

Abdel-Sater M, El-Said A (2001) Xylan-decomposing fungi and xylanolytic activity in agricultural and industrial wastes. Int Biodeterior Biodegradation 47:15-21

Adsul M, Sharma B, Singhania RR, Saini JK, Sharma A, Mathur A, Gupta R, Tuli DK (2014) Blending of cellulolytic enzyme preparations from different fungal sources for improved cellulose hydrolysis by increasing synergism. RSC Adv 4:44726-44732
Ahirwar S, Soni H, Prajapati BP, Kango N (2017) Isolation and screening of thermophilic and thermotolerant fungi for production of hemicellulases from heated environments. Mycology 8(3):125-134

Ali A, Muid S (2012) Effect of media and temperature on growth and preliminary detection of ligninolytic and cellulolytic activity of Trametes spp. Borneo J Resour Sci Technol 2:33-40

Ang S, Shaza E, Adibah Y, Suraini A, Madihah M (2013) Production of cellulases and xylanase by Aspergillus fumigatus SK1 using untreated oil palm trunk through solid state fermentation. Process Biochem 48:1293-1302

Arora R, Behera S, Sharma NK, Singh R, Yadav YK, Kumar S (2014) Biochemical conversion of rice straw (Oryza sativa L.) to bioethanol using thermotolerant isolate K. marxianus NIRE-K3. In: Sharma NR, Thakur RC, Sharma M, Parihar L, Kumar G (eds) Proceedings of exploring \& basic sciences for next generation frontiers. Elsevier, New Delhi, pp 143-146

Arora R, Behera S, Kumar S (2015) Bioprospecting thermophilic/thermotolerant microbes for production of lignocellulosic ethanol: a future perspective. Renew Sustain Energy Rev 51:699-717

Bagewadi ZK, Ninnekar HZ (2015) Production, purifiation and characterization of endoglucanase from Aspergillus fumigatus and enzymatic hydrolysis of lignocellulosic waste. Int J Biotechnol Biomed Sci 1:25-32

Bailey MJ, Biely P, Poutanen K (1992) Interlaboratory testing of methods for assay of xylanase activity. J Biotechnol 23:257-270

Bairagi S (2016) Isolation, screening and selection of fungal strains for potential cellulase and xylanase production. Int J Pharm Sci Invent 5(3):1-6

Behera S, Arora R, Kumar S (2013) Bioprospecting the cellulases and xylanases thermozymes for the production of biofuels. In: Paper presented at AICHE annual meeting, San Francisco, 3-8 November, 2013

Behera S, Arora R, Nandhagopal N, Kumar S (2014) Importance of chemical pretreatment for bioconversion of lignocellulosic biomass. Renew Sustain Energy Rev 36:91-106

Birhanli E, Yesilada O (2006) Increased production of laccase by pellets of Funalia trogii ATCC 200800 and Trametes versicolor ATCC 200801 in repeatedbatch mode. Enzyme Microb Technol 39:1286-1293

Bradford MM (1976) A rapid and sensitive method for the quantitation of microgram quantities of protein utilizing the principle of protein-dye binding. Anal Biochem 72:248-254

Bradner J, Gillings M, Nevalainen K (1999) Qualitative assessment of hydrolytic activities in Antarctic microfungi grown at different temperatures on solid media. World J Microbiol Biotechnol 15:131-132

de Vries RP, Visser J (2001) Aspergillus enzymes involved in degradation of plant cell wall polysaccharides. Microbiol Mol Biol Rev 65:497-522

Edberg SC, Trepeta RW, Kontnick CM, Torres AR (1985) Measurement of active constitutive beta-D-glucosidase (esculinase) in the presence of sodium desoxycholate. J Clin Microbiol 21:363-365

Florencio C, Couri S, Farinas CS (2012) Correlation between agar plate screening and solid-state fermentation for the prediction of cellulase production by Trichoderma strains. Enzyme Res. https://doi. org/10.1155/2012/793708

Ford M (2014) Medical microbiology. Oxford University Press, Oxford

Fu K, Fu S, Zhan H, Zhou P, Liu M, Liu H (2013) A newly isolated wood-rot fungus for laccase production in submerged cultures. BioResources 8:1385-1397

Galhaup C, Wagner H, Hinterstoisser B, Haltrich D (2002) Increased production of laccase by the wood-degrading basidiomycete Trametes pubescens. Enzyme Microb Technol 30:529-536

Gao J, Weng H, Zhu D, Yuan M, Guan F, Xi Y (2008) Production and characterization of cellulolytic enzymes from the thermoacidophilic fungal Aspergillus terreus M11 under solid-state cultivation of corn stover. Bioresour Technol 99:7623-7629

Garvey M, Klose H, Fischer R, Lambertz C, Commandeur U (2013) Cellulases for biomass degradation: comparing recombinant cellulase expression platforms. Trends Biotechnol 31:581-593

Ghose T (1987) Measurement of cellulase activities. Pure Appl Chem 59:257-268

Grigorevski-Lima A, Da Vinha F, Souza D, Bispo A, Bon E, Coelho R, Nascimento R (2009) Aspergillus fumigatus thermophilic and acidophilic endoglucanases. Appl Biochem Biotechnol 155:18-26

Grover AK, MacMurchie DD, Cushley RJ (1977) Studies on almond emulsin $\beta d$-glucosidase I. Isolation and characterization of a bifunctional isozyme. Biochim Biophys Acta (BBA)-Enzymol 482:98-108 
Hölker U, Höfer M, Lenz J (2004) Biotechnological advantages of laboratoryscale solid-state fermentation with fungi. Appl Microbiol Biotechnol 64:175-186

Hou H, Zhou J, Wang J, Du C, Yan B (2004) Enhancement of laccase production by Pleurotus ostreatus and its use for the decolorization of anthraquinone dye. Process Biochem 39:1415-1419

Ibrahim C (2008) Development of applications of industrial enzymes from Malaysian indigenous microbial sources. Bioresour Technol 99:4572-4582

Juturu V, Wu JC (2014) Microbial cellulases: engineering, production and applications. Renew Sustain Energy Rev 33:188-203

Khokhar I, Haider MS, Mushtaq S, Mukhtar I (2012) Isolation and screening of highly cellulolytic filamentous fungi. J Appl Sci Environ Manag 16:223-226

Kluepfel D (1988) Screening of prokaryotes for cellulose-and hemicellulosedegrading enzymes. In: Wood WA, Kellogg ST (eds) Methods in enzymology, vol 160. Elsevier, Amsterdam, pp 180-186

Kovács K, Szakacs G, Zacchi G (2009) Comparative enzymatic hydrolysis of pretreated spruce by supernatants, whole fermentation broths and washed mycelia of Trichoderma reesei and Trichoderma atroviride. Bioresour Technol 100:1350-1357

Kwon KS, Lee J, Kang HG, Hah YC (1994) Detection of $\beta$-glucosidase activity in polyacrylamide gels with esculin as substrate. Appl Environ Microbiol 60:4584-4586

Lalita, Prasher IB (2014) Qualitative screening of lignocellulolytic enzymes in wood rotting Agaricomycetes from North Western Himalayas. J Adv Bot Zool. https://doi.org/10.15297/JABZ.V113.07

Lynd LR, Weimer PJ, Van Zyl WH, Pretorius IS (2002) Microbial cellulose utilization: fundamentals and biotechnology. Microbiol Mol Biol Rev 66:506-577

Madhavi V, Lele S (2009) Laccase: properties and applications. BioResources 4:1694-1717

Mallerman J, Papinutti L, Levin L (2015) Characterization of $\beta$-glucosidase produced by the white rot fungus Flammulina velutipes. J Microbiol Biotechnol 25:57-65

Manavalan T, Manavalan A, Heese K (2015) Characterization of lignocellulolytic enzymes from white-rot fungi. Curr Microbiol 70:485-498

Mandels M, Weber J (1969) The production of cellulases. Adv Chem 95:391-414

Meddeb-Mouelhi F, Moisan JK, Beauregard M (2014) A comparison of plate assay methods for detecting extracellular cellulase and xylanase activity. Enzyme Microb Technol 66:16-19

Narasimha Ramulu K, Benarjee G (2016) Diversity and distribution of macrophytes in Nagaram tank of Warangal district, Telangana state

Noratiqah K, Madihah M, Aisyah BS, Eva MS, Suraini A, Kamarulzaman K (2013) Statistical optimization of enzymatic degradation process for oil palm empty fruit bunch (OPEFB) in rotary drum bioreactor using crude cellulase produced from Aspergillus niger EFB1. Biochem Eng J 75:8-20

Olajuyigbe FM, Nlekerem CM, Ogunyewo OA (2016) Production and characterization of highly thermostable $\beta$-glucosidase during the biodegradation of methyl cellulose by Fusarium oxysporum. Biochem Res Int. https:// doi.org/10.1155/2016/3978124

Pandey A, Soccol CR, Mitchell D (2000) New developments in solid state fermentation: I-bioprocesses and products. Process Biochem 35:1153-1169

Pečiulyte D (2007) Isolation of cellulolytic fungi from waste paper gradual recycling materials. Ekologija 53(4):11-18

Pointing SB (1999) Qualitative methods for the determination of lignocellulolytic enzyme production by tropical fungi. Fungal Divers 2:17-33

Polizeli M, Rizzatti A, Monti R, Terenzi H, Jorge JA, Amorim D (2005) Xylanases from fungi: properties and industrial applications. Appl Microbiol Biotechnol 67:577-591

Prasertsan P, H-kittikul A, Chitmanee B (1992) Isolation and selection of cellulolytic fungi from palm oil mill effluent. World J Microbiol Biotechnol 8:614-617

Raimbault M (1998) General and microbiological aspects of solid substrate fermentation. Electron J Biotechnol 1:26-27
Ramanjaneyulu G, Reddy GPK, Kumar KD, Reddy BR (2015) Isolation and screening of xylanase producing fungi from forest soils. Int J Curr Microbiol App Sci 4:586-591

Revankar MS, Lele S (2006) Enhanced production of laccase using a new isolate of white rot fungus WR-1. Process Biochem 41:581-588

Ruegger MJS, Tauk-Tornisielo SM (2004) Atividade da celulase de fungos isolados do solo da Estação Ecológica de Juréia-Itatins, São Paulo, Brasil. Rev Bras Bot 27:205-211

Sánchez C (2009) Lignocellulosic residues: biodegradation and bioconversion by fungi. Biotechnol Adv 27:185-194

Sandhya C, Sumantha A, Szakacs G, Pandey A (2005) Comparative evaluation of neutral protease production by Aspergillus oryzae in submerged and solid-state fermentation. Process Biochem 40:2689-2694

Saqib AAN, Whitney PJ (2006) Esculin gel diffusion assay (EGDA): a simple and sensitive method for screening $\beta$-glucosidases. Enzyme Microb Technol 39:182-184

Sherief A, El-Tanash A, Atia N (2010) Cellulase production by Aspergillus fumigatus grown on mixed substrate of rice straw and wheat bran. Res J Microbiol 5:199-211

Singh S, Dutt D, Tyagi C (2013) Screening of xylanases from indigenously isolated white rot fungal strains for possible application in pulp biobleaching. Open Access Sci Rep 2:262

Singhania RR, Sukumaran RK, Patel AK, Larroche C, Pandey A (2010) Advancement and comparative profiles in the production technologies using solid-state and submerged fermentation for microbial cellulases. Enzyme Microb Technol 46(7):541-549

Singhania RR, Patel AK, Sukumaran RK, Larroche C, Pandey A (2013) Role and significance of beta-glucosidases in the hydrolysis of cellulose for bioethanol production. Bioresour Technol 127:500-507

Sohail M et al (2009) Distribution of hydrolytic enzymes among native fungi: Aspergillus the pre-dominant genus of hydrolase producer. Pak J Bot 41:2567-2582

Suwannarangsee S, Bunterngsook B, Arnthong J, Paemanee A, Thamchaipenet A, Eurwilaichitr L, Laosiripojana N, Champreda V (2012) Optimisation of synergistic biomass-degrading enzyme systems for efficient rice straw hydrolysis using an experimental mixture design. Bioresour Technol 119:252-261

Teather RM, Wood PJ (1982) Use of Congo red-polysaccharide interactions in enumeration and characterization of cellulolytic bacteria from the bovine rumen. Appl Environ Microbiol 43:777-780

Tekere M, Zvauya R, Read JS (2001) Ligninolytic enzyme production in selected sub-tropical white rot fungi under different culture conditions. J Basic Microbiol 41:115-129

Thurston CF (1994) The structure and function of fungal laccases. Microbiology 140:19-26

Veena V, Poornima P, Parvatham R, Kalaiselvi K (2011) Isolation and characterization of $\beta$-glucosidase producing bacteria from different sources. Afr J Biotechnol 10:14891-14906

Wood PJ, Erfle JD, Teather RM (1988) Use of complex formation between Congo Red and polysaccharides in detection and assay of polysaccharide hydrolases. In: Wood WA, Kellogg ST (eds) Methods in enzymology, vol 160. Elsevier, Amsterdam, pp 59-74

Xu X, Lin M, Zang Q, Shi S (2018) Solid state bioconversion of lignocellulosic residues by Inonotus obliquus for production of cellulolytic enzymes and saccharification. Bioresour Technol 247:88-95

Xue DS, Liang LY, Zheng G, Lin DQ, Zhang QL, Yao SJ (2017) Expression of Piromyces rhizinflata cellulase in marine Aspergillus niger to enhance halostable cellulase activity by adjusting enzyme-composition. Biochem Eng J 117:156-161

Yadav SK (2017) Technological advances and applications of hydrolytic enzymes for valorization of lignocellulosic biomass. Bioresour Technol. https://doi.org/10.1016/.biortech.2017.05.066

Yamada R, Hasunuma T, Kondo A (2013) Endowing non-cellulolytic microorganisms with cellulolytic activity aiming for consolidated bioprocessing. Biotechnol Adv 31:754-763 